\title{
Prática da meditação em salas de aula da graduação (licenciaturas) na universidade pública.
}

\section{Graziella Toffolo Luiz*, Rogério Adolfo de Moura.}

\section{Resumo}

Inspirada em pesquisas internacionais sobre meditação em universidades, uma vez que ainda existem poucas pesquisas no Brasil sobre o assunto, a presente pesquisa desenvolveu práticas de meditação guiada (silenciosa e com a postural corporal adaptada à cadeira na sala de aula), de alguns minutos, por algumas semanas seguidas em disciplinas de estágios de licenciatura para alunos de graduação da Universidade Estadual de Campinas (UNICAMP). Por meio de postulados teóricos diversos, mas especialmente os estudos da mente e os estudos do corpo, buscou-se verificar se a meditação propiciaria uma nova relação entre o corpo e a mente dos estudantes dentro da sala de aula ao inserir momentos breves de silêncio e contemplação num ambiente que está tomado o tempo todo por atividade e ação, seja por meio do uso da palavra, seja por meio do pensamento. Através de questionários, pintura de desenhos e depoimentos verificou-se diversos benefícios nos estudantes universitários que praticaram, o que abre caminho para novos pesquisas de como a meditação pode se tornar uma prática mais recorrente na educação brasileira.

\section{Palavras-chave:}

Meditação, Estudos do Corpo, Ensino Superior.

\section{Introdução}

Algumas pesquisas de meditação já estão sendo feitas no âmbito educacional, principalmente no nível internacional. Um estudo realizado por pesquisadores de duas universidades e de um centro médico dos EUA revisou várias experiências de meditação realizadas no ensino superior pelo mundo. A pesquisa notou benefícios em três aspectos diferentes: "melhoria da performance cognitiva e acadêmica, gestão dos relatos acadêmicos de stress e desenvolvimento integral da pessoa" (SHAPIRO; BROWN; ASTIN, 2008, p. 9) 1.

Dessa forma, essa pesquisa buscou começar a suprir a lacuna de pesquisas brasileiras sobre o tema por mio do desenvolvimento da prática de meditação guiada (silenciosa e sentada em cadeira) para estudantes de disciplinas de estágio de licenciatura da UNICAMP, investigando quais impactos essa prática é capaz de proporcionar.

\section{Resultados e Discussão}

Após a aprovação do Comitê de Ética em Pesquisa da UNICAMP, a pesquisadora entrou em contato por email com os professores das disciplinas de estágio de licenciatura, sendo que seis deles permitiram que a pesquisa fosse realizada em dois semestres.

A forma de coletar dados nesta pesquisa se baseou em desenhos anônimos feitos pelos estudantes, nos quais eles puderam se desenhar como eles se sentiam antes e como se sentiam depois de meditar e em questionários anônimos respondidos pelos estudantes. Os questionários possuíam perguntas abertas e fechadas que investigaram a dificuldade dos alunos se concentrarem na aula, os impactos que a meditação ocasionou nos estudantes e o interesse deles pela prática meditativa.

Os resultados dos questionários demonstraram que após a meditação mais de $95 \%$ dos estudantes se sentiram mais relaxados, $82 \%$ dos estudantes se sentiram mais concentrados e $98 \%$ dos estudantes gostariam que a prática da meditação fosse expandida para outras disciplinas que cursam.
Antes da meditação em muitos desenhos e nas respostas dos questionários os estudantes demonstram estar preocupados e agitados, o que evidencia uma separação entre mente e corpo, ou seja, o corpo estava presente, mas a mente estava agitada. Após a meditação, os estudantes se representaram por meio dos desenhos e as cores utilizadas demonstraram estados mais calmos e relaxados, tornando a relação corpo e mente mais harmoniosa.

Figura 1. Desenho anônimo de um estudante da Unicamp após meditar

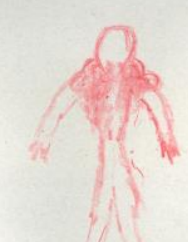

\section{Conclusões}

Antes da meditação os estudantes demonstram estar preocupados e agitados, o que evidencia uma separação entre mente e corpo, ou seja, o corpo estava presente, mas a mente estava agitada. Após a meditação a relação corpo e mente estava mais harmoniosa. Logo, os resultados da pesquisa apontam para a necessidade de refletir a respeito da relação entre o corpo e a mente dos estudantes na sala de aula.

\section{Agradecimentos}

Programa Institucional de Bolsas de Iniciação Científica - SAE

${ }^{1}$ SHAPIRO, S. L.; BROWN, K. W.; ASTIN, J. A. Toward the Integration of Meditation into Higher Education: A Review of Research. Santa Fe: Five Directions Consulting, 2008. 